\title{
Evaluation of Pharmacokinetics, Antibacterial and Anti-Inflammatory Activities of Chrysin in Rat
}

\author{
Falguni Modi $^{1 *}$, S.K. Bhavsar ${ }^{2}$, J.H. Patel ${ }^{1}$, R.D. Varia $^{1}$, L.C. Modi ${ }^{3}$ and Nitin Kale ${ }^{1}$ \\ ${ }^{1}$ Department of Veterinary Pharmacology and Toxicology, ${ }^{3}$ Department of Veterinary \\ Gynecology, College of Veterinary Sci. \& A.H, Navsari Agricultural University, \\ Navsari, Gujarat, India \\ ${ }^{2}$ Department of Veterinary Pharmacology and Toxicology, College of Veterinary Sci. \& A.H, \\ Anand Agricultural University, Anand, Gujarat, India \\ *Corresponding author
}

A B S T R A C T

The pharmacokinetics, antibacterial and anti-inflammatory activities of Chrysin (100 $\mathrm{mg} / \mathrm{kg}$ ) were studied following intramuscular administration in rats. Drug concentration in rat plasma was determined using High Performance Liquid Chromatography (HPLC). The

Keywords

Antibacterial, Antiinflammatory, Pharmacokinetic, Chrysin, Rat

Article Info

Accepted:

10 August 2018

Available Online:

10 September 2018 mean peak plasma drug concentration of $0.24 \pm 0.01 \mu \mathrm{g} / \mathrm{mL}$ was achieved at $0.25 \mathrm{~h}$. The pharmacokinetic parameters like elimination half-life $\left(\mathrm{t}_{1 / 2 \beta}\right)$, apparent volume of distribution $\left(\mathrm{Vd}_{\text {area }}\right)$ and total body clearance of Chrysin were $0.52 \pm 0.03 \mathrm{~h}, 338.63 \pm 13.39$ $\mathrm{L} / \mathrm{kg}$ and $456.20 \pm 15.62 \mathrm{~L} / \mathrm{h} / \mathrm{kg}$ respectively were determined. In vitro and in vivo antibacterial activity of Chrysin was determined by microbroth dilution technique against different bacterial pathogens and in neutropenic rat intraperitoneal infection model, respectively. In the present study, Chrysin was found to have no in vitro antibacterial activity in range of $10-0.07 \mathrm{mg} / \mathrm{mL}$. In in vivo bacterial colony count between test drug and positive drug (Chloramphenicol) indicated that Chrysin had no protective activity against Staphylococcus aureus in neutropenic rat intraperitoneal infection model. In the present study, Chrysin found to inhibit LPS induced nitric oxide production on RAW 264.7 macrophage cell line and COX-2 enzyme through ELISA method but significantly $(\mathrm{p}<0.01)$ lower to Meloxicam. In addition to this Chrysin $(100 \mathrm{mg} / \mathrm{kg})$ was found to be effective $(34.67 \pm 1.55 \%)$ in carrageenan-induced paw edema assay in rat after $4 \mathrm{~h}$ following intramuscular administration.

\section{Introduction}

Chrysin is a naturally present flavone found in various herbs, mushroom and propolis (Premratanachai and Chanchao, 2014). It possess anti-inflammatory (Yao et al., 2016), antiaging (Souza et al., 2015), antiviral (Wang et al., 2014) antioxidant (Freitas and Gaspar, 2016) antidiabetes (Samarghandian et al., 2016), antiaromatase (Oliveira et al., 2012) and anticancer (Zhang et al., 2016) activities. However, it has poor bioavailability following oral administration (Noh et al., 2016) as parent compound. Despite the great potential 
data on its intramuscular pharmacokinetic are completely lacking and it's in vitro and in vivo antibacterial and anti-inflammatory activity of Chrysin as pure compound are limited. Looking to above facts, present study was undertaken to study pharmacokinetic of Chrysin following single intramuscular administration $(100 \mathrm{mg} / \mathrm{kg}$ b.wt.) in rats and evaluate in vitro and in vivo antibacterial and anti-inflammatory activities.

\section{Materials and Methods}

\section{Experimental animals}

The experiment was conducted on male albino wistar rats weighing between 300 to 400 grams. Rats were kept under constant observation for two weeks before the commencement of the experiment and subjected to clinical examination to exclude possibility of any diseases. The animals were divided into groups and kept in cages. Standard ration and water was provided ad libitum. The experimental protocol was approved by Institutional Animal Ethics Committee.

\section{Drug and chemical}

Pure chrysin, iodonitrotetrazolium chloride, meloxicam sodium (>98\%), Lambda $(\lambda)$ carrageenan, Lipopolysacharide (LPS) were obtained from Sigma-Aldrich, St. Louis, USA. Dimethysulfoxide (DMSO), PEG200, Methanol, Acetonitrile, Glacial acetic acid, Ortho-Phosphoric acid, Normal Saline (NS) and Sodium Nitrite were purchased from Merck Specialities Private Limited, Mumbai. Ethanol was used from store of College of Veterinary Science and A.H., N.A.U., Navsari after triple distillation. Gentamicin sulphate, Cyclophosphamide, Chloramphenicol, Dulbecco's modified Eagle's medium (DMEM), Penicillin, Streptomycin, Sulfanilamide, Naphthyl ethylene diaminedihydrochloride (NED), 3-(4,5dimethythiazol-2-yl)-2,5-diphenyltetrazolium bromide (MTT) were purchased from Himedia Laboratories Private Limited, Mumbai. Murine macrophage cell line RAW 264.7 was purchased from National Centre for Cell Science (NCCS), Pune. COX (ovine) inhibitor screening assay kit (Item No.560101) was purchased from Cayman Chemical Company, Ann Arbor, MI 48108.

\section{Pharmacokinetic study and data analysis}

Animals $(n=30)$ were divided into six groups and each group comprise of five animals. A single dose of Chrysin was given by intramuscular route in each group of animal at dose rate $100 \mathrm{mg} / \mathrm{kg} \mathrm{B.W}$. Blood samples (250 $\mu \mathrm{l})$ were collected from treated rat in K3EDTA vials, at different time interval i.e., 0 (before drug administration), 0.08 (5 $\mathrm{min}$ ), 0.25 (15 min), 0.5 (30 min), 1, 2, 4, 6, 8, 12, 18 and 24hours from retro orbital plexus under light anesthesia. Multiple numbers of rat were used for serial collection of blood at alternating time point. Blood samples were subjected to centrifugation at $5000 \mathrm{rpm}$ for 10 minutes and separated plasma samples were transferred to cryo-vials to store at $-20^{\circ} \mathrm{C}$. Samples were analyzed within $24-48 \mathrm{~h}$ to quantify Chrysin levels using High Performance Liquid Chromatography (HPLC). Chrysin was assayed in plasma by adopting procedure with minor modifications as described by Bruschi et al., (2003). The High Performance Liquid Chromatography (HPLC) apparatus of Shimadzu (Japan) comprised of binary gradient delivery pump (model LC 20AP), Diode Array Detector (model SPD M20A), Auto Sampler (model SIL 20A) and reverse phase $\mathrm{C} 18$ column $(250 \times 4.6 \mathrm{~mm}$ ID).For plasma protein precipitation, Acetonitrile and Glacial acetic acid mixture (9:1 ratio) was added in plasma (1:1 ratio) in a clean micro centrifuge tube and subjected to a vortex mixer for 1 minute. It was followed by 
centrifugation for 15 minutes at $8000 \mathrm{rpm}$. The clean supernatant was transferred into inserts (automatic sampler vial) from which 20 $\mu \mathrm{L}$ of supernatant was injected into HPLC system. The mobile phase consisted of a mixture of ACN and water (70:30). Mobile phase was filtered by $0.2 \mu$ size filter (Axiva N66) and degassed by ultra-sonication. The mobile phase was pumped into column at a flow rate of $1.0 \mathrm{~mL} / \mathrm{min}$ at ambient temperature. The effluent was monitored at $257 \mathrm{~nm}$ wavelength. Various pharmacokinetic parameters were calculated from plasma concentration of Chrysin using software PK solution (Version 2.0). For plasma validation of HPLC method, initial stock solution of Chrysin was prepared by dissolving $2 \mathrm{mg}$ pure Chrysin in $2 \mathrm{~mL}$ DMSO and PEG200 in 1:1 ratio. Final standards were prepared in drugfree rat plasma. The mean correlation coefficient $\left(\mathrm{R}^{2}\right)$ was 0.99 for calibration curves. The precision and accuracy of the assay were assessed using samples at concentration of 12.50, 1.56, 0.39 and 0.09 $\mu \mathrm{g} / \mathrm{mL}$. At all concentration studied, the C.V. of Chrysin was less than $6.78 \%$.

\section{In vitro antibacterial activity of chrysin}

Minimum inhibitory concentrations (MICs) of Chrysin was determined in range of $10-0.07$ $\mathrm{mg} / \mathrm{ml}$ for different organisms like Staphylococcus aureus (ATCC25923), Escherichia coli (ATCC25922), Salmonella typhimurium (ATCC23564), Pseudomonas aerugonosa (ATCC27853), Streptococcus pyogenus (ATCC8668), Proteus mirabilis (NCIM2241) and Bacillus subtillis (ATCC9372) by micro broth dilution technique.

\section{In vivo antibacterial activity of chrysin}

In vivo antibacterial efficacy of chrysin was evaluated in neutropenic rat intraperitoneal infection model. Bacterial suspensions of
Staphylococcus aureus was prepared in sterile broth and adjusted to $1 \times 10^{8} \mathrm{CFU} / \mathrm{mL}$ (McFarland 0.5 standard) by measuring the OD of solutions at $620 \mathrm{~nm}$, from overnight grown bacteria. CFUs were verified by plating serial dilutions of each inoculum onto nutrient agar. For induction of neutropenia in albino wistar rats, Cyclophosphamide was inject intraperitoneally on day $1(150 \mathrm{mg} / \mathrm{kg})$ and day $4(100 \mathrm{mg} / \mathrm{kg})$. On day 5 neutropenic condition was confirmed by determination of total leucocyte count from all animals by Blood Auto Analyzer (Exigo, USA). After confirmation the rats were infected by intraperitoneal injection of $0.2 \mathrm{ml}$ of inoculum $\left(1 \times 10^{8} \mathrm{cfu} / \mathrm{mL}\right)$ on same day. Chrysin was administered intramuscularly at $2 \mathrm{~h}$ and $8 \mathrm{~h}$ post infection. After $24 \mathrm{~h}$, peritoneal fluid samples $(100 \mu \mathrm{L})$ were collected following euthanasia and inoculated on nutrient agar plates. Nutrient agar plates were incubated overnight at $37^{\circ} \mathrm{C}$ and bacterial colonies were enumerated by colony counter. Rats were divided into four groups $(n=6)$. Group I animals were treated with bacterial suspension (0.2 $\mathrm{mL}, \quad 1 \times 10^{8} \mathrm{cfu} / \mathrm{mL}, \quad$ IP) and Chloramphenicol (50 mg/kg, IM) (positive control), Group II animals were treated with bacterial suspension $\left(0.2 \mathrm{~mL}, 1 \times 10^{8} \mathrm{cfu} / \mathrm{mL}\right.$, IP) (growth control), Group III animals were treated with bacterial suspension $(0.2 \mathrm{ml}$, $\left.1 \times 10^{8} \mathrm{cfu} / \mathrm{mL}, \mathrm{IP}\right)$ and vehicle $(0.2 \mathrm{~mL}, \mathrm{IM})$ (vehicle control), Group IV animals were treated with bacterial suspension $(0.2 \mathrm{~mL}$, $\left.1 \times 10^{8} \mathrm{cfu} / \mathrm{mL}, \mathrm{IP}\right)$ and Chrysin $(100 \mathrm{mg} / \mathrm{kg}$, IM).

\section{In vitro anti-inflammatory activity of chrysin}

\section{COX-2 enzyme inhibition assay}

The chrysin and meloxicam were dissolved in $100 \%$ Methanol to prepare a stock concentration of $1 \mathrm{mM} / 100 \mathrm{~mL}$. The test compound was tested in triplicates at different 
concentrates $(100 \mu \mathrm{M}, 50 \mu \mathrm{M}$ and $10 \mu \mathrm{M})$ by using a commercial COX (ovine) inhibitor screening assay kit following procedure as recommended by the manufacturer. Cyclooxygenase catalyzes the first step in the biosynthesis of Arachidonic acid to PGH2 and thereafter PGF $2 \alpha$ produced from $\mathrm{PGH} 2$ by reduction with stannous chloride was measured by enzyme immunoassay. This assay is based on the competition between PGs and a PG-acetyl cholinesterase conjugate (a PG tracer) for a limited amount of PG antiserum. The amount of PG tracer that is able to bind to the PG antiserum is inversely proportional to the concentration of PGs in the wells, since the concentration of the PG tracer is held constant while PG concentration varies. This antibody-PG complex binds to an anti-IgG antibody previously attached to the well. The plate was washed with a buffer solution and Ellman's reagent, which contains the substrate of acetylcholinesterase, was added to the well. The yellow product of this enzymatic reaction is determined spectrophotometrically in a Microplate Reader (Multiskan EX, Thermo scientific) at 450 $\mathrm{nm}$.Results were expressed as percentage of inhibition of PGF $2 \alpha$ production.

\section{Determination of NO production}

The murine macrophage cell line RAW 264.7 cells were grown and maintained in DMEM (Dulbecco's Modified Eagle Medium) supplemented with $20 \%$ FBS, $100 \mathrm{U} / \mathrm{mL}$ penicillin and $100 \mu \mathrm{g} / \mathrm{mL}$ streptomycin. The culture was incubated at $37^{\circ} \mathrm{C}$ in humidified atmosphere and $5 \% \mathrm{CO}_{2}$ until the cells were confluent.

The cells then washed and resuspended in DMEM. The cells were seeded in 12 well plate ( 1 x $10^{6}$ cells per well) and incubated for 24 hours at $37^{\circ} \mathrm{C}$ in a humidified atmosphere and $5 \% \quad \mathrm{CO}_{2}$ and were sub cultured twice before the experiment.
The medium (DMEM supplemented with $10 \%$ FBS and $100 \mathrm{U} / \mathrm{mL}$ penicillin and streptomycin) then washed and supplemented with $1600 \mu \mathrm{L}$ growth medium and $200 \mu \mathrm{L}$ Chrysin and Meloxicam (positive control) in different concentration $(100 \mu \mathrm{M}, 50 \mu \mathrm{M}$ and $10 \mu \mathrm{M})$ then incubated for 2 hours. $200 \mu \mathrm{L}$ LPS $(1 \mu \mathrm{g} / \mathrm{mL})$ was added into the medium and incubated for 24 hours at $37^{\circ} \mathrm{C}$ in a humidified atmosphere and $5 \% \mathrm{CO}_{2}$. After pre-incubation of RAW 264.7 cells with LPS $(1 \mu \mathrm{g} / \mathrm{ml})$ for $24 \mathrm{~h}$, the quantity of nitrite accumulated in the culture medium was measured as an indicator of NO production based on the Griess reaction (Hevel and Marletta, 1994).100 $\mu$ of cell culture medium was mixed with $100 \mu \mathrm{L}$ of Griess reagent $(1 \%$ sulfanilamide and $0.1 \%$ naphthyl ethylene diaminedihydrochloride in $2.5 \%$ phosphoric acid). The Mixture was incubated at room temperature for $10 \mathrm{~min}$ and the absorbance at $540 \mathrm{~nm}$ was measured in spectrophotometer (Halo DB-20, Dynamica). The quantitative estimation of nitrite is based on a sodium nitrite standard calibration curve. The assay was performed in triplicate.

\section{In vivo Anti-inflammatory activity of Chrysin}

The carrageenan-induced paw edema test was used with slight modification as described (Suebsasana et al., 2009). Experimental animals were divided into four groups $(n=6)$. All the animals were treated with $100 \mu \mathrm{L}$ of $1 \%$ lambda carrageenan solution in $0.9 \%$ normal saline subcutaneously into subplantar region of right hind paw. Half an hour before the carrageenan challenge, vehicle, test and positive control drugs were injected via intramuscular route. Group I animals act as carrageenan control, Group II animals were treated intramuscularly with $200 \mu \mathrm{L}$ of DMSO: PEG200 (1:1) (vehicle control), Group III animals were treated with Meloxicam (5 mg/kg, IM), Group IV animals 
were treated with Chrysin (100 mg/kg IM). Make a mark on the left hind paw and volume of the edematous paw was measured using a plethysmometer after carrageenan treatment at $0,1,2,3,4,5$ and $6 \mathrm{~h}$. Edema was expressed as the increase in paw volume $(\mathrm{mL})$ after carrageenan injection, in comparison to the pre-injection value for each animal. The results obtained for the Chrysin treated group was compared with the control for percent inhibition of edema.

\section{Statistical analysis}

Chrysin plasma concentration and pharmacokinetic parameters of different treatment groups were compared by students' " $t$ " test and Duncan's New Multiple Range Test (DNMRT) at 1 per cent and 5 per cent level of significance.

\section{Results and Discussion}

\section{Pharmacokinetics of Chrysin in rats}

Pharmacokinetic parameters and semilogarithmic plot of drug concentration in plasma versus time following single dose intramuscular administration of Chrysin (100 $\mathrm{mg} / \mathrm{kg}$ ) in rats is depicted in table 1 and figure 1. In the present study following intramuscular administration of Chrysin $(100 \mathrm{mg} / \mathrm{kg})$ in rats, the mean peak $\left(\mathrm{C}_{\max }\right)$ plasma drug concentration of $0.24 \pm 0.01 \mu \mathrm{g} / \mathrm{mL}$ was achieved at $0.25 \mathrm{~h} \quad\left(\mathrm{~T}_{\max }\right)$. The drug concentration of $0.15 \pm 0.01 \mu \mathrm{g} / \mathrm{mL}$ in plasma was detected at $1 \mathrm{~h}$ and beyond then the drug was not detected in plasma. Contrary to the present observation high peak plasma drug concentration of $32.08 \pm 7.98 \mu \mathrm{g} / \mathrm{mL}$ was observed in rats (Aishwarya and Sumathi, 2016) and low plasma drug concentration of $0.09 \pm 0.01 \mu \mathrm{g} / \mathrm{mL}$ in rats (Tong et al., 2012) and $0.01 \mu \mathrm{g} / \mathrm{mL}$ in human (Walle et al., 2000) were reported following oral administration. Moreover Chrysin was not detected at all in plasma (Noh et al., 2016).The elimination half-life $\left(\mathrm{t}_{1 / 2 \beta}\right)$, apparent volume of distribution $\left(\mathrm{Vd}_{\text {area }}\right)$ and total body clearance of Chrysin following single dose intramuscular administration in the present study was $0.52 \pm 0.03 \mathrm{~h}, \quad 338.63 \pm 13.39 \mathrm{~L} / \mathrm{kg}$ and $456.20 \pm 15.62 \mathrm{~L} / \mathrm{h} / \mathrm{kg}$ respectively. However, longer elimination half-life of $1.75 \pm 0.16 \mathrm{~h}$ (Aishwarya and Sumathi, 2016) and 9.72 \pm 3.16 $\mathrm{h}$ and lower total body clearance of $2.72 \pm 0.67$ $\mathrm{L} / \mathrm{h} / \mathrm{kg}$ (Tong et al., 2012) in rats following oral administration were observed in rats. Following intravenous administration of Chrysin in rats, Noh et al., (2016) observed shorter half-life $(0.04 \pm 0.01 \mathrm{~h})$, lower apparent volume of distribution $(0.4 \pm 0.1 \mathrm{~L} / \mathrm{kg})$ and lower total body clearance $(7.40 \pm 1.30 \mathrm{~L} / \mathrm{h})$. The MRT values calculated following single dose intramuscular administration of Chrysin in present study was $0.83 \pm 0.05 \mathrm{~h}$ which was lower than MRT of $10.20 \pm 1.40 \mathrm{~h}$ observed following oral administration of Chrysin in rats (Tong et al., 2012).

\section{In vitro and in vivo antibacterial activity of Chrysin}

In vitro and in vivoantibacterial activity of Chrysin was determined by microbroth dilution technique against different bacterial pathogens and in neutropenic rat intraperitoneal infection model, respectively and result shown in table 2 . In the present study the Chrysin was found to have no in vitro antibacterial activity in range of 10-0.07 $\mathrm{mg} / \mathrm{mL}$. In in vivo bacterial colony count between test drug and positive drug (Chloramphenicol) indicated that Chrysin had no protective activity against Staphylococcus aureus in neutropenic rat intraperitoneal infection model. However, Nina et al., (2015) observed MICs $>50 \mu \mathrm{g} / \mathrm{mL}$ for Chrysin against methicillin-sensitive Staphylococcus aureus (ATCC 25923), methicillin-resistant Staphylococcus aureus (ATCC 43300), Escherichia coli (ATCC 25922), Escherichia 
coli 121, Escherichia coli 122, Escherichia coli LM2, Salmonella sp. LM and Proteus mirabilis 94-2. Several scientists also observed antibacterial effect of crude extract containing Chrysin and other secondary metabolite on different bacterial organism (Darwish et al., 2010; Liu et al., 2010; Wang et al., 2011; Alves et al., 2013).

The difference in in vitro activity of Chrysin as pure compound may be due hydrophobicity, method of susceptibility and interaction with other compounds in crude extract. Chrysin did not show in vivo antibacterial activity in neutropenic intraperitoneal infection (Staphylococcus aureus) model which may be due to non-buildup of required drug concentrations in plasma or at site of infection after intramuscular administration because faster clearance of the drug and that may be due to rapid hepatic metabolism (Noh et al., 2016).

Table.1 Pharmacokinetic parameters of chrysin $(100 \mathrm{mg} / \mathrm{kg})$ following intramuscular administration in rats

\begin{tabular}{|c|c|c|c|c|c|c|c|c|}
\hline \multirow{2}{*}{$\begin{array}{c}\text { Pharmacoki- } \\
\text {-netic } \\
\text { Parameter }\end{array}$} & \multicolumn{7}{|c|}{ Rat Number } & \multirow[t]{2}{*}{ Mean \pm S.E } \\
\hline & Unit & R1 & $\mathbf{R 2}$ & R3 & R4 & R5 & R6 & \\
\hline$\alpha$ & $\mathrm{h}^{-1}$ & 12.26 & 13.17 & 11.38 & 13.35 & 11.63 & 7.95 & $11.62 \pm 0.80$ \\
\hline $\bar{\beta}$ & $h^{-1}$ & 1.43 & 1.27 & 1.21 & 1.11 & 1.39 & 1.76 & $1.36 \pm 0.09$ \\
\hline$t_{1 / 2 \alpha}$ & $\mathrm{h}$ & 0.057 & 0.053 & 0.061 & 0.052 & 0.060 & 0.087 & $0.06 \pm 0.01$ \\
\hline$\overline{t_{1 / 2 \beta}}$ & $\mathrm{h}$ & 0.48 & 0.55 & 0.57 & 0.62 & 0.50 & 0.39 & $0.52 \pm 0.03$ \\
\hline $\mathrm{C}_{\max }$ & $\mu \mathrm{g} / \mathrm{mL}$ & 0.27 & 0.23 & 0.23 & 0.24 & 0.23 & 0.26 & $0.24 \pm 0.01$ \\
\hline $\mathbf{T}_{\max }$ & $\mathrm{h}$ & 0.25 & 0.25 & 0.25 & 0.25 & 0.25 & 0.25 & $0.25 \pm 0.00$ \\
\hline$\overline{\mathrm{AUC}_{(0-\infty)}}$ & $\mu \mathrm{g} \cdot \mathrm{h} / \mathrm{mL}$ & 0.23 & 0.23 & 0.22 & 0.25 & 0.20 & 0.20 & $0.22 \pm 0.01$ \\
\hline AUMC & $\mu \mathrm{g} \cdot \mathrm{h}^{2} / \mathrm{mL}$ & 0.18 & 0.20 & 0.20 & 0.24 & 0.16 & 0.13 & $0.18 \pm 0.02$ \\
\hline $\mathbf{V} \mathbf{d}_{\text {(area) }}$ & $\mathrm{L} / \mathrm{kg}$ & 308.31 & 341.87 & 371.86 & 366.09 & 354.23 & 289.38 & $338.63 \pm 13.49$ \\
\hline $\mathrm{Cl}_{(\mathrm{B})}$ & $\mathrm{L} / \mathrm{h} / \mathrm{kg}$ & 441.79 & 434.59 & 450.74 & 407.21 & 493.71 & 509.19 & $456.20 \pm 15.62$ \\
\hline MRT & h & 0.78 & 0.85 & 0.90 & 0.98 & 0.79 & 0.65 & $0.83 \pm 0.05$ \\
\hline
\end{tabular}

Table.2 In vivo activity of chrysin against Staphylococcus aureus in neutropenic rat intraperitoneal infection model

\begin{tabular}{|c|c|c|c|c|c|c|c|}
\hline \multirow[t]{3}{*}{ Group } & \multicolumn{6}{|c|}{$\begin{array}{l}\text { Bacterial Colony Count } \\
\left(\log _{10} \text { CFU/mL) }\right.\end{array}$} & \multirow[t]{3}{*}{ Mean \pm S.E } \\
\hline & \multicolumn{6}{|c|}{ Rat Number } & \\
\hline & R1 & $\mathbf{R 2}$ & $\mathbf{R 3}$ & R4 & R5 & R6 & \\
\hline Growth control & 8.71 & 8.63 & 8.49 & 8.58 & 8.78 & 8.76 & $8.66 \pm 0.05^{b}$ \\
\hline Vehicle control & 8.70 & 8.66 & 8.60 & 8.76 & 8.56 & 8.58 & $8.64 \pm 0.03^{b}$ \\
\hline Chrysin & 8.81 & 8.78 & 8.69 & 8.71 & 8.59 & 8.74 & $8.72 \pm 0.03 b^{b}$ \\
\hline Chloramphenicol & 4.48 & 4.52 & 4.45 & 4.38 & 4.57 & 4.60 & $4.50 \pm 0.03^{\mathrm{a}}$ \\
\hline
\end{tabular}

Means bearing different superscripts within a column (between treatment groups) differ significantly $(p<0.01)$ 
Table.3 In vitro inhibition effect of chrysin on COX-2 enzyme

\begin{tabular}{|c|c|c|c|}
\hline \multirow{2}{*}{ Group } & \multicolumn{3}{|c|}{$\begin{array}{c}\text { Percent inhibition }(\text { Mean } \pm \text { SE) of COX-2 at different } \\
\text { drug concentrations }(\mu \mathrm{M})\end{array}$} \\
\cline { 2 - 4 } & $\mathbf{1 0 0}$ & $\mathbf{5 0}$ & $\mathbf{1 0}$ \\
\hline Meloxicam & $80.24 \pm 0.39^{\mathrm{b}}$ & $60.78 \pm 0.70^{\mathrm{b}}$ & $33.02 \pm 0.70^{\mathrm{b}}$ \\
\hline Chrysin & $11.14 \pm 0.48^{\mathrm{a}}$ & $6.90 \pm 0.77^{\mathrm{a}}$ & $1.57 \pm 0.34^{\mathrm{a}}$ \\
\hline
\end{tabular}

Means bearing different superscripts within a column (between treatment groups) differ significantly $(\mathrm{p}<0.01)$

Table.4 Percent inhibition (Mean \pm SE) of NO production by chrysin

\begin{tabular}{|c|c|c|c|}
\hline \multirow[t]{2}{*}{ Group } & \multicolumn{3}{|c|}{$\begin{array}{l}\text { Percent inhibition (Mean } \pm \text { SE) of NO production at different drug } \\
\text { concentrations }(\mu M)\end{array}$} \\
\hline & 100 & 50 & 10 \\
\hline Indomethacin & $63.27 \pm 3.40$ & - & - \\
\hline Chrysin & $53.88 \pm 2.12$ & $39.19 \pm 3.35$ & $24.52 \pm 7.06$ \\
\hline
\end{tabular}

Table.5 Percent inhibition of edema by chrysin in rats

\begin{tabular}{|c|c|c|c|c|c|c|}
\hline \multirow[t]{2}{*}{ Group } & \multicolumn{6}{|c|}{ Percent inhibition of edema (Mean \pm SE) } \\
\hline & 1 Hour & 2 Hour & 3 Hour & 4 Hour & 5 Hour & 6 Hour \\
\hline Meloxicam & $23.99 \pm 3.41^{\mathrm{b}}$ & $24.70 \pm 0.99^{b}$ & $36.97 \pm 2.02^{b}$ & $34.70 \pm 1.85^{\mathrm{b}}$ & $39.46 \pm 1.82^{b}$ & $43.52 \pm 1.35^{\mathrm{b}}$ \\
\hline Chrysin & $14.82 \pm 2.32^{\mathrm{a}}$ & $4.66 \pm 3.87^{\mathrm{a}}$ & $5.89 \pm 4.30^{\mathrm{a}}$ & $14.64 \pm 3.46^{\mathrm{a}}$ & $26.38 \pm 2.76^{\mathrm{a}}$ & $34.67 \pm 1.55^{\mathrm{a}}$ \\
\hline
\end{tabular}

Fig.1 Semilogarithmic plot of Chrysin concentration in plasma versus time following single dose intramuscular administration of Chrysin $(100 \mathrm{mg} / \mathrm{kg})$ in rats. Each points represents mean \pm S.E.

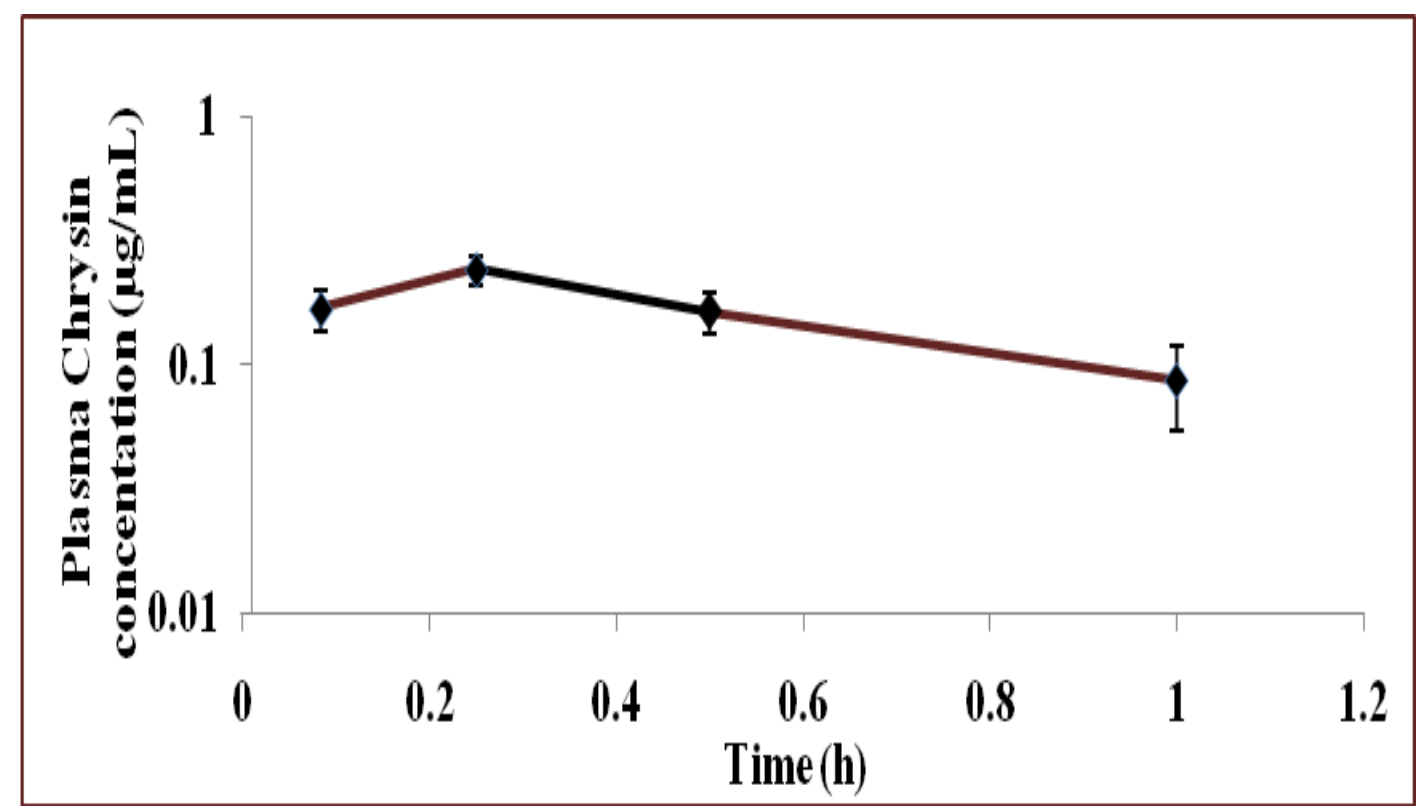


In vitro and in vivoanti-inflammatory activity of Chrysin

In the present study, Chrysin found to inhibit LPS induced nitric oxide production on RAW 264.7 macrophage cell line and COX-2 enzyme through ELISA method but significantly $(\mathrm{p}<0.01)$ lower to Meloxicam and Indomethacin (Table 3 and 4). In addition to this Chrysin $(100 \mathrm{mg} / \mathrm{kg})$ was found to be effective $(34.67 \pm 1.55 \%)$ in carrageenaninduced paw edema assay in rat after $4 \mathrm{~h}$ following intramuscular administration (Table 5). Results of the present in vitro assay are in agreement with the results reported by several workers like Woo et al., (2005) found significant suppression of LPS-induced COX2 enzyme and mRNA expression in a dosedependent manner; Ha et al., (2010) observed significant inhibition of nitric oxide (NO) release, expressions of inducible NO synthase (iNOS) and cyclooxygenase-2 (COX-2) in lipopolysaccharide (LPS) stimulated microglia; Leeand Park, (2015) also observed significant inhibition the production of NO in polyinosinic-polycytidylic acid induced RAW 264.7 mouse macrophages; Kaidama and Gacche, (2015) exhibited significant inhibition in carrageenan-induced acute inflammation and chronic inflammation/cotton pellet granuloma in guinea pigs at $40 \mathrm{mg} / \mathrm{kg}$ following oral administration of Chrysinand Rauf et al., (2015) observed significant reduction of mice paw edema and its maximum effect was observed between the 4hand 5hfollowing intraperitoneal injection of Chrysin. The in vivo anti-inflammatory activity observed from $4 \mathrm{~h}$ onwards in the present study may be due to inhibition of prostaglandin synthesis. In vitro COX-2 enzyme inhibition in the present study supports the observation of in vivo antiinflammatory activity. The in vivo antiinflammatory activity observed from 4 hour onwards in the present study may be due to inhibition of prostaglandin synthesis. In vitro
COX-2 enzyme inhibition in the present study supports the observation of in vivo antiinflammatory activity.

\section{Acknowledgement}

The facility and infrastructure provided by Dean, College of Veterinary science and A. H., Navsari to conduct this study is duly acknowledged.

\section{Conflict of interest statement}

Authors declare that they have no conflict of interest.

\section{References}

Aishwarya, V. and Sumathi, T. 2016. Enhanced blood-brain barrier transmigration using the novel Chrysin embedded solid lipid nanoformulation: A salient approach on physico-chemical characterization, pharmacokinetics and biodistribution studies. International Journal of Pharmaceutical and Clinical Research, 8(12): 1574-1582.

Alves, M.J., Ferreira, I.C.F.R., Froufe, H.J.C., Abreu, R.M.V., Martins, A. and Pintado, M. 2013. Antimicrobial activity of phenolic compounds identified in wild mushrooms, SAR analysis and docking studies. Journal of Applied Microbiology, 4:1-12.

Bruschi, M. L., Franco, M.L., and Gremia, M. P. D. 2003. Application of an HPLC method for analysis of propolisextract. Journal of Liquid Chromatography \& Related Technologies, 26(14): 23992409.

Darwish, R. M., Fares, R. J. A., Zarga, M. H. A and Nazer, I.K. 2010. Antibacterial effect of Jordanian propolis and isolated flavonoids against human pathogenic bacteria. African Journal of Biotechnology, 9(36): 5966-5974. 
Freitas, J.V. and Gaspar, L.R. 2016.In vitro photo safety and efficacy screening of Apigenin, Chrysin and beta-carotene for UVA and VIS protection. Eur J Pharm Sci., 89:146-53.

Ha, S.K., Moon, E. and Kim, S.Y. 2010. Chrysin suppresses LPS-stimulated proinflammatory responses by blocking $\mathrm{NF}-\kappa \mathrm{B}$ and JNK activations in microglia cells. Neurosci. Lett., 485(3):143-7.

Hevel, J.M. and Marletta, M.A.1994. Nitric oxide synthase assays. Methods Enzymol, 233: 250 - 258.

Kaidama, W. and Gacche, R. 2015. AntiInflammatory activity of Chrysin in acute and chronic phases of inflammation in guinea pigs. International Journal of Scientific and Research Publications, 5(2):1-4.

Lee, J. and Park, W. 2015. Anti-inflammatory effect of Chrysin on RAW 264.7 mouse macrophages induced with polyinosinic-polycytidylic acid. Biotechnology and Bioprocess Engineering, 20(6):1026-1034.

Liu, H., Mou, Y., Zhao, J., Wang, J., Zhou, L., Wang, M., Wang, D., Han, J., Yu, Z. and Yang, F. 2010. Flavonoids from Halostachyscaspica and their antimicrobial and antioxidant activities. Molecules, 15(11):7933-45.

Nina, N., Quispe, C., Jiménez-Aspee, F., Theoduloz, C., Feresín, G.E., Lima, B., Leiva, E. and Schmeda-Hirschmann, G. 2015. Antibacterial activity, antioxidant effect and chemical composition of propolis from the Region del Maule, Central Chile. Molecules, 20:1814418167.

Noh, K., Oh, D., Nepal, M., Jeong, K., Choi, Y., Kang, M., Kang, W., Jeong, H. and Jeong, T. 2016. Pharmacokinetic interaction of Chrysin with Caffeine in rats. Biomol. Ther., 24(4):446-452.
Oliveira, G.A., Ferraz, E.R., Souza, A.O., Lourenco, R.A, Oliveira, D.P. and Dorta, D.J. 2012. Evaluation of the mutagenic activity of Chrysin, a flavonoid inhibitor of the aromatization process. J Toxicol Environ Health. 75(16-17):1000-1011.

Premratanachai, P. and Chanchao, C. 2014. Review of the anticancer activities of bee products. Asian Pac J Trop Biomed., 4(5):337-44.

Rauf, A., Khan, R., Raza, M., Khan, H., Pervez, S., De Feo, V., Maione, F. and Mascolo, N. 2015. Suppression of inflammatory response by Chrysin, a flavone isolated from Potentillaevestita Th. Wolf. Insilico predictive study on its mechanistic effect. Fitoterapia, 103:129-35.

Samarghandian, S., Azimi-Nezhad, M., Samini, F. and Farkhondeh T. 2016. Chrysin treatment improves diabetes and its complications in liver, brain, and pancreas in streptozotocin-induced diabetic rats. Can J Physiol Pharmacol., 94 (4):388-393.

Souza, L.C., Antunes, M.S., Filho, C.B., Del Fabbro, L., De Gomes, M.G., Goes, A.T., Donato, F., Prigol, M. and Boeira, S.P. 2015. Flavonoid Chrysin prevents age-related cognitive decline via attenuation of oxidative stress and modulation of BDNF levels in aged mouse brain. Jesse CR Pharmacol Biochem Behav., 134:22-30.

Suebsasana, S., Pongnaratorn, P., Sattayasai, J., Arkaravichien, T., Tiamkao, S. and Aromdee, C. 2009. Analgesic, antipyretic, anti -inflammatory and toxic effects of andrographolide derivatives in experimental animals. Arch Pharm Res, 32:1191-1200.

Tong, L., Wan, M., Zhan, L., Zhu, Y., Sun, H. and Bi, K. 2012. Simultaneous determination of Baicalin, Wogonoside, Baicalein, Wogonin, Oroxylin A and 
Chrysin of Radix scutellariae extract in rat plasma by liquid chromatography tandem mass spectrometry. Journal of Pharmaceutical and Biomedical Analysis, 70: 6- 12.

Walle, T., Otake, Y., Brubaker, J. A., Walle, U. K. and Halushka, P. V. 2000. Disposition and metabolism of the flavonoid Chrysin in normal volunteers. Br J ClinPharmacol., 51:143-146.

Wang, J., Qiu, J., Dong, J., Li, H., Luo, M., X. Dai, Zhang, Y., Leng, B., Niu, X., Zhao, S. and Deng, X. 2011. Chrysin protects mice from Staphylococcus aureus pneumonia. Journal of Applied Microbiology, 111:1551-1558.

Woo, K., Jeong, Y., Inoue, H., Park, J. and Kwon, T. 2005. Chrysin suppresses lipopolysaccharide- induced cyclo oxygenase-2 expression through the inhibition of nuclear factor for IL-6 (NF-IL6) DNA-binding activity. FEBS Letters, 579(3):705-711.

Yao, J., Jiang, M., Zhang, Y., Liu, X., Du, Q. and Feng, G. 2016.Chrysin alleviates allergic inflammation and airway remodeling in a murine model of chronic asthma. Int. Immunopharmacol., 32:24-31.

Zhang, P., Gou, Y., Gao, X., Bai, R., Chen, W., Sun, B., Hu, F. and Zhao, W. 2016. The pharmacokinetic study of Rutin in rat plasma based on an electrochemically reduced grapheme oxide modified sensor. Journal of Pharmaceutical Analysis, 6:80-86.

\section{How to cite this article:}

Falguni Modi, S.K. Bhavsar, J.H. Patel, R.D. Varia, L.C. Modi and Nitin Kale. 2018. Evaluation of Pharmacokinetics, Antibacterial and Anti-Inflammatory Activities of Chrysin in Rat. Int.J.Curr.Microbiol.App.Sci. 7(09): 1494-1503. doi: https://doi.org/10.20546/ijcmas.2018.709.179 